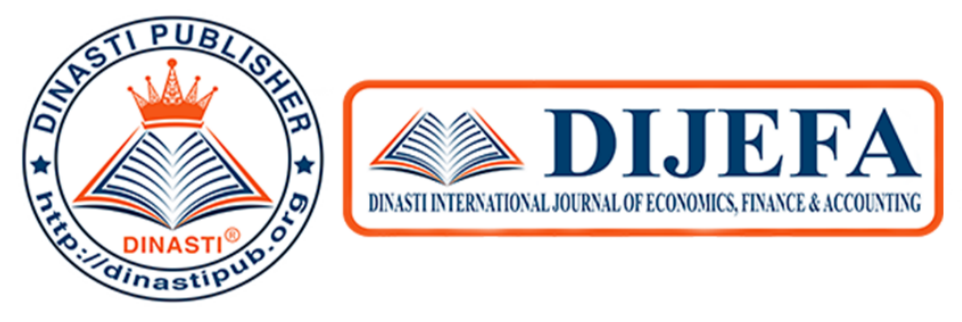

+6281387654578 (9)

+6281387654578 (2)

https://dinastipub.org/DIJEFA (-) dinasti-info@gmail.com @.

\title{
FINANCIAL DISTRESS AND TAX MOTIVATION: THE EFFECT ON EARNINGS MANAGEMENT
}

\author{
Reschiwati $^{1}$, Harwin Hasudungan ${ }^{3}$ \\ ${ }^{1)}$ Sekolah Tinggi Ilmu Ekonomi Y.A.I Jakarta \\ 2) ABFII Perbanas Jakarta
}

\begin{tabular}{|c|c|}
\hline $\begin{array}{l}\text { IRTICLE INFORMATION } \\
\text { Received : } 3 \text { August } 2020 \\
\text { Revised: } 25 \text { August } 2020 \\
\text { Issued: } 24 \text { September } 2020 \\
\text { Corresponding author : } \\
\text { Reschiwati } \\
\text { E-mail : } \\
\text { echireschiwati@yahoo.com } \\
\end{array}$ & $\begin{array}{l}\text { Abstract: When companies solve financial distress, } \\
\text { there are efforts made by companies such as } \\
\text { accounting methods, changing accounting } \\
\text { estimation, policies, and shifting periods of costs or } \\
\text { revenues. Companies also often carry out strategies } \\
\text { in dealing with deferred taxes or tax payments, both } \\
\text { of which are done is a form of earnings management } \\
\text { This study aims to discuss the effect of financial } \\
\text { distress and tax motivation on earnings } \\
\text { management in transportation service companies } \\
\text { approved in the Indonesia Stock Exchange in 2014- } \\
\text { 2018. Sampling using a purposive sampling } \\
\text { technique. From a population of } 35 \text { companies, } \\
\text { based on the criteria chosen } 9 \text { companies were } \\
\text { selected as samples. Data processing using panel } \\
\text { data regression method. Based on the selection } \\
\text { model, the fixed effect is chosen as the analysis } \\
\text { model to be used. The results of the study concluded } \\
\text { that financial distress determines a significant } \\
\text { positive effect on earnings management while tax } \\
\text { motivation does not involve earnings management. } \\
\text { Keywords: Earnings Management, Financial } \\
\text { Distress, Tax Motivation }\end{array}$ \\
\hline
\end{tabular}

\section{INTRODUCTION}

Financial statements are often used as indicators of management performance appraisal. To get good performance, management can do earnings management. Earnings management behavior is possible because management has more and more accurate information compared to the principal. When a company experiences financial problems (financial distress), there are efforts made by the company such as changes in accounting methods, changing accounting estimation policies, and shifting periods of cost or income (Yuliana, 2011). This may be applied because the accrual accounting policy is applied through the treatment of transactions relating to earnings that approach the expected value expected by the company's management. The use of accrual basis will enable the achievement of matching concept and matching principle. Research (M. Humeedat, 2018) shows that earnings management is not influenced by the Altman Zscore index and has a negative relationship between cash flow from operations and discretionary accruals. Meanwhile according to (Gupta \& Suartana, 2018) financial distress has a positive and significant effect on earnings management.

In addition, one of the things that can affect earnings management behavior is tax motivation. Companies generally prepare different financial statements between financial statements for commercial with financial statements for fiscal according (Khalida \& Tarmizi, 2015) this will cause differences in accounting earnings and fiscal earnings. The differences occur due to the basis used in the preparation of different 
financial statements. Accounting profits are prepared based on generally accepted accounting principles in Indonesia (GAAP), while fiscal profits are prepared based on taxation regulations. The difference between accounting income and temporary fiscal profit will cause deferred tax burden. Deferred tax analysis can be an alternative for external parties as users of financial statements and other parties associated with the company to assess whether a company carries out earnings management or not through the deferred tax component for the purpose of preventing loss reporting. Deffered tax is a delay in tax payment by a company, as a result of a temporary difference between accounting profit and fiscal profit. Basically, accounting and taxation expenses or revenues are actually the same, but the allocation is different every year. One to find out how a company applies tax motivation is to look at the company's treatment in assessing deferred tax and corporate income tax in the financial statements of the company. According to (Yulianti, 2005) identified that deferred tax expense and accrual actions (using the Total Accruals model, Modified Jones Model and Forward Looking Model) have a positive and significant impact on the probability of earnings management to avoid losses. However, according to (Dewi \& Ulupui, 2014) shows income tax has a negative effect on earnings management, where tax is not the main reason for companies to take earnings management actions.

From the explanation above, it can be seen that the results of research examining the effect of financial distress and tax motivation on earnings management give different research results and conclusions. Therefore it is necessary to conduct further research on financial distress and tax motivation on earnings management.

\section{LITERATURE REVIEW \\ Agency Theory}

According to (Jensen \& Meckling, 1976) that Agency Theory is built as an attempt to solve understand and solve problems that arise when there is incompleteness of information when entering into a contract (engagement). Agency theory describes the relationship between shareholders as shareholders and management as agents. Management is a contracted party by shareholders to work in the interests of shareholders. Because they are chosen, the management must account for all their work to shareholders. (Jensen \& Meckling, 1976) describes agency relationships as "agency relationships as a contract under which one or more people (the principals) engage another person (the agent) to perform some service on their behalf which involves delegating some decision making authority to the agent ". If both parties have the same goal to maximize the value of the company, then it is believed that the agent will act in a manner consistent with the principal's interests. In agency theory, agency relationships arise when one or more people (principals) employ another person (agent) to provide a service and then delegate decision making authority to the agent. The relationship between principal and agent can lead to a condition of information imbalance because the agent is in a position that has more information about the company than the principal. Assuming that individuals act to maximize their own interests, then the asymmetric information they have will encourage agents to hide some information that is not known to the principal. In these asymmetric conditions, the agent can influence the accounting numbers presented in the financial statements by way of earnings management (Rinaldi, 2015).

\section{Signaling Theory}

According to (Brigham \& Houston, 2011) Signaling Theory is an action taken by the management of a company that provides instructions for investors about how management views the company's prospects. Companies with favorable prospects will try to avoid selling shares and seeking every new capital needed by other means, including the use of debt.

Signaling theory according to (Hartono, 2005) states that a good quality company will intentionally give a signal to the market, thus the market is expected to be able to distinguish between companies that are of good and bad quality. In order for this signal to be good it must be able to be captured by the market and be perceived well and not easily imitated by companies that have poor quality.

This theory will reveal that investors can differentiate between high-value companies and low-value companies by observing ownership of their capital structure and marking high valuations for hightly levered companies. Equilibrium is stable 
because low value companies cannot imitate higher companies (Rinaldi, 2015). Signaling theory suggests how a company should give signals to users of financial statements. This signal is in the form of information about what has been done by management to realize the wishes of the owner. Signals can be in the form of promotions or other information stating that the company is better than other companies. Signal theory explains that giving signals is done by managers to reduce information asymmetry. Managers provide information through financial statements that they implement conservatism accounting policies that produce quality earnings because this principle prevents companies from making an act of enlarging profits and helps users of financial statements by presenting quality earnings and assets (Magister Akuntansi, 2015).

\section{Earning Management}

According to Healy and Wallen in Sri Sulistyanto (2008: 50) earnings management is: "Earnings management occurs when using certain decisions in financial statements and transactions to change financial statements as a basis for evaluating company performance aimed at misleading shareholders or shareholders, or to influence contractual results that rely on the accounting numbers reported. Earnings management can occur because given the flexibility to choose the accounting method that will be used in recording and disclosing private financial information. In addition, this manipulation behavior also occurs due to high information asymmetry between management and other parties who do not have adequate resources, encouragement, or access to information to monitor management. So that management will try to manipulate the company's performance for its own sake ".

According to (Gupta \& Suartana, 2018) to measure earnings management is done using discretionary accrual proxy using the Modified Jones Model because based on Dechow et al. (1995) this model is better than the standard Jones model in measuring income manipulation cases. This model subtracts non-discretionary accruals to total accruals to obtain discretionary accruals.

According to Scott (2000) in (Anasta, 2015) there are several motivations that encourage managers to manage earnings, namely bonus motivation, other contractual motivation, political motivation, tax motivation, CEO turnover, Initial Public Offering, and providing information to investors. Management performs earnings management so that the company's financial statements look better. This is due to the tendency of investors to look at financial statements in assessing a company. In general, investors are more interested in the company's financial performance in the future and will use the reported earnings at this time to review the possibility of what will happen in the future. Earnings management is divided into real earnings management and accrual earnings management. Real earnings management are management actions that deviate from normal business practices carried out with the main objective of achieving profit targets. Real earnings management can be done in 3 (three) ways, namely: (1) Sales manipulation, (2) Decreasing discretionary expenses; (3) Overproduction. (Roychowdhury, 2006) provides empirical evidence that companies carry out real earnings management to avoid reporting losses. (Zang, 2006) shows empirical evidence that real earnings management actions are carried out before accrual-based earnings management. Accrual earnings management is indicated by the existence of discretionary accruals. Research that analyzes earnings management by looking at discretionary accruals was conducted by (Hayn, 1995) which states that earnings management can be carried out by management when the company is still growing, even when corporate profits fall near zero. (Degeorge, Jayendu Patel, \& Richard Zeckhauser, 1999) state that growth companies report increased profits to achieve analysts' earnings forecasts. In various ways, managers influence analyst forecasting to manage earnings to be precise with forecasting. In addition, (Myers \& Skinner, 2000) states that earnings management in growth companies is not strong because it is difficult to separate earnings management from a legitimate accounting policy for growth companies. 


\section{Financial Distress}

According to Platt (2002) in (Gupta \& Suartana, 2018) financial distress as a condition of the company is experiencing irregularities and financial pressures that will gradually lead to bankruptcy. According to (Theodorus \& Hapsari, 2017) If a company fails or is unable to meet its obligations, the company can be said to be experiencing financial distress. Bankruptcy begins with financial distress, which is a situation where the company is unable to pay obligations when due which causes the company to go bankrupt, or causes a case agreement with creditors to reduce or write off its debt (Munawir, 2010).

Financial distress can be measured by various models and methods. One form of measurement that is often and widely used in researching financial distress is the financial distress model from Altman. Altman found a formula that can be used to detect company bankruptcy with a very well-known term, Z-score. Z-score is a score obtained from financial ratios such as liquidity, profitability, leverage and solvency. Then the results of this ratio are multiplied by a certain weight. According to Platt (2002) financial distress in (Gupta \& Suartana, 2018) as a condition of the company is experiencing irregularities and financial pressures that will gradually lead to bankruptcy. Financial distress can be measured using the Altman Z Score model.

\section{Tax Motivation}

In general, the notion of motivation can be interpreted as a goal or driving force which becomes the main driving force for someone in trying to get or achieve what they want both positively and negatively (Setiani, Andini, \& Oemar, 2018). According to (Law of the Republic of Indonesia Number 16 Year 2009), Tax is a mandatory contribution to the State owed by individuals or entities that are forced based on the law by not getting a direct reward and used for the State's needs for the maximum prosperity of the people. Tax functions as a tool to regulate and implement government policies in the social and economic fields. Taxes are assumed to be costs that greatly affect the company in relation to profits. Economically, tax is an element of profit reduction available to companies. Taxes are things that cannot be denied by companies. As long as the company fulfills the requirements as a taxpayer, the company must carry out its duties in paying taxes. Companies often want to minimize the cost of spending for taxes, it is because with low taxes, the company's capital to carry out activities becomes even greater. That is what motivates companies to minimize taxes. Motivation to pay taxes is a potential strength of taxpayers who can be from within or outside individual taxpayers. Motivation from outside the taxpayer can come from the environment, relatives, coworkers, taxation apparatuses that encourage to pay taxes (Setiani, Andini, \& Oemar, 2018).

\section{Financial Distress and Earnings Management}

According to (Gupta \& Suartana, 2018) to measure earnings management is done by using a discretionary accrual proxy using the Modified Jones Model because it is based (Dechow \& Sweeney, 1995) this model is better than the standard Jones model in measuring income manipulation cases. Based on research results obtained through statistical testing that financial distress has a positive and significant effect on earnings management. According to (Tresnaningsih, 2008) this research found that companies that have high free cash flow accompanied by low growth opportunities (HFLG) are more likely to do discretionary accruals that increase profits. Based on this, the hypothesis built is:

H1: There is an influence of Financial Distress on earnings management

\section{Tax Motivation and Earnings Management}

(Harnanto, 2011) states that deferred tax expense is an expense arising from temporary differences between accounting earnings (earnings in financial statements for external parties) and fiscal profits (earnings used as a basis for calculating taxes). The difference between accounting and fiscal financial statements is caused in the preparation of financial statements, accounting standards provide more flexibility for management in determining accounting principles and assumptions than is allowed according to tax regulations (Yulianti, 2005). Temporary difference is the difference between the total tax recorded assets or liabilities with the Tax Imposition Base (DPP) 
on these assets or liabilities. The time difference occurs because of differences in recognition of the amount of time in commercial accounting compared with fiscal. The difference between the recognition difference between commercial accounting earnings and fiscal accounting that will result in a correction in the form of a positive correction and a negative correction. Positive corrections will result in deferred tax assets, while negative corrections will result in deferred tax expense. (Amanda \& Febrianti, 2015). Phillips et al. (2003) in (Irreza \& Yulianti, 2012) believes that earnings management is created due to the discretion made by managers of accounting choices and cash flows from operating activities. Phillips et al. (2003) and Yulianti (2005) in (Irreza \& Yulianti, 2012) argue that by using alternative income differences according to accounting with earnings according to taxation, can help separate the problem of discretion carried out by managers with normal operating activities or we can call it non-discretionary, compared to using accrual proxies. Phillips et al. (2004) in (Irreza \& Yulianti, 2012) believes that earnings management activities by raising profits according to accounting are earnings management that maximizes profits without having to increase costs associated with the corporate tax. The research of Phillips et al. (2004) use changes in net deferred tax liabilities as a proxy for differences in earnings according to accounting with taxation in (Irreza \& Yulianti, 2012). Based on this, the hypotheses built are:

$\mathrm{H} 2$ : There is an influence of Tax Motivation on Earnings Management

\section{Research design}

The relationship model between variables for this study is described as follows:

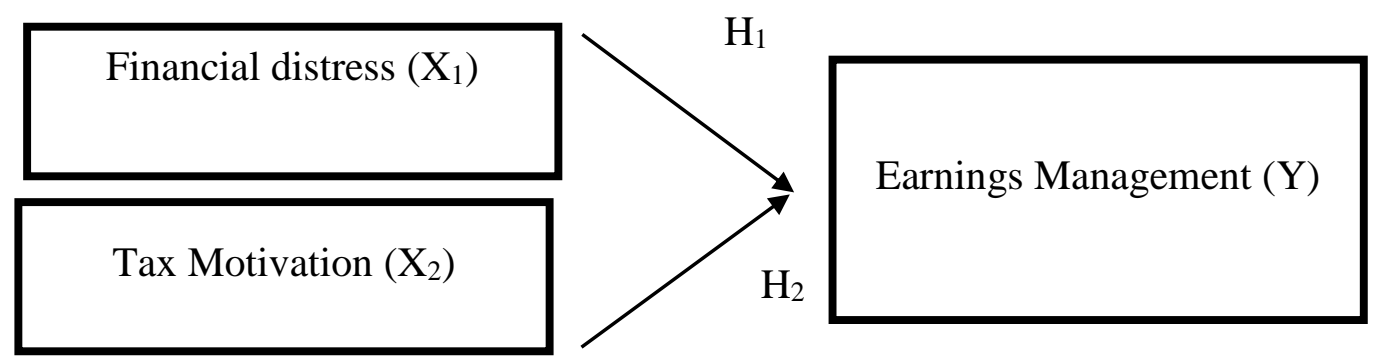

Figure 1 Research Design

\section{RESEARCH METHODS \\ Variable Operations \\ Earnings management}

To measure earnings management is done by using a discretionary accrual proxy using the Modified Jones Model (Gupta \& Suartana, 2018). The calculation model is as follows:

TAit $=$ NIit - CFOit

Then calculate the total accrual value (TAC) estimated with the following regression equation:

TAit/TAit- $1=\alpha i(1 /$ TAit- 1$)+\beta 1$ i $(\Delta$ REVit/TAit-1 $) \beta 2$ i $($ PPEit $/$ TAit- 1$)+\varepsilon$

By using the regression coefficient above, the nondiscretionary accrual (NDTA) value can be calculated using the formula:

NDTAit $=\alpha \mathrm{i}(1 /$ TAit- 1$)+\beta 1 \mathrm{i}((\Delta$ REVit- $\Delta$ RECit $) /$ TAit -1$)+\beta 2 \mathrm{i}($ PPEit/TAit- 1$)+\varepsilon \ldots . . .(3)$

Discretionary accrual (DTA) is the residual obtained from the estimated total accrual calculated as follows:

DTAit $=($ TAit/TAit-1)-NDTAit

Information:

DTAit $=$ Discretionary accrual of company $\mathrm{i}$ in period $\mathrm{t}$

NDTAit $=$ Non-Discretionary employeercc $\mathrm{i}$ in period $\mathrm{t}$

Niit $=$ Net income of company $\mathrm{i}$ in period $\mathrm{t}$

Tait $=$ Total accrual of company $\mathrm{i}$ in period $\mathrm{t}$

CFOit = Flow of operating cash flow of company $i$ in period $t$

TAit-1 = Total assets of company $\mathrm{i}$ in period $\mathrm{t}-1$

$\triangle$ REVit $=$ Change in sales of company $\mathrm{i}$ in period $\mathrm{t}$

PPEit = Company's fixed assets in period $\mathrm{t}$

$\triangle$ RECit $=$ Change in company receivables $\mathrm{i}$ in period $\mathrm{t}$ 


\section{Financial Distress}

Financial distress will be measured using the Altman $\mathrm{Z}$ Score model.

$$
\mathrm{Z}=\mathrm{X} 1+\mathrm{X} 2+\mathrm{X} 3+\mathrm{X} 4
$$

$$
\mathrm{Z}=6,56 \mathrm{X} 1+3,26 \mathrm{X} 2+6,72 \times 3+1,05 \mathrm{X} 4 \text {. }
$$

Information:

$\mathrm{Z}=\mathrm{Z}$-Score Index

$\mathrm{X} 1$ = Loan / Deposit Ratio (loans / third party funds)

X2 = Retained Earning / Total Assets

X3 = Earning Before Interest and Tax / Total Assets

X4 = Market Value of Equity to Book Value of Total Debt (total capital / total debt) Based on the $\mathrm{Z}$-score equation, the $\mathrm{Z}$ value is obtained as follows: if the value of $\mathrm{Z}>$ 2.60 , it can be categorized in a healthy condition (safe zone), if the value of $1.1<\mathrm{Z} \leq$ 2.60 , it can be categorized as a company that is prone to bankrupt conditions, and if the value of $Z \leq 1.1$, the company can be categorized in a bankrupt condition.

\section{Tax Motivation}

Tax Motivation is proxied by comparing the total assets of the previous year with the deferred tax expense of the company in the most recent year (DTE / Ait-1). 


\section{Population and Sample}

The population in this study is the transportation sector companies listed on the Indonesia stock exchange in 2014-2018. The companies sampled in this study were transportation sector service companies that were listed on the Indonesia Stock Exchange (IDX) in 2014-2018. The sampling technique uses a purposive sampling method with the following criteria: (1) Transportation sector service companies listed on the Indonesia Stock Exchange in 2014 to 2018; (2) Published financial statements that have been audited by independent auditors as of December 31, consecutively from 2014-2018, (3) There are Deferred Tax Expenses on the statement of financial position, (4) Registered on the Indonesia Stock Exchange before 2014; (4) The company uses the rupiah currency and if using foreign currency is translated into rupiah with the BI middle rate reference; (5) The financial statements contain complete information relating to the research. Based on established criteria, there are 9 companies that are sampled.

\section{Classic assumption test \\ Multicollinearity Test}

To test the presence or absence of multicollinearity, Tolerance and VIF (variance inflation factor) values can be used. If the Tolerance value is more than 0.1 and the VIF value is less than 10, then it shows no multicollinearity (Gupta \& Suartana, 2018).

\section{Heteroscedasticity Test}

To detect heteroscedasticity, the Glejser test is used. If the independent variable does not affect the dependent variable then there will be no heteroscedasticity symptoms. A regression model is said to contain no symptoms of heteroscedasticity if the significance is above 0.05 (Gupta \& Suartana, 2018).

\section{Autocorrelation Test}

To find out whether there is autocorrelation, the Durbin-Watson method (DW-test) is used. The DW-test values are then compared with the DW table values using a 5\% significance level (Gupta \& Suartana, 2018).

Selection of Panel Data Regression Method

To choose the most appropriate model used in managing panel data, there are 3 tests that must be performed, namely (1) Chow Test, namely testing to determine the Fixed Effect or Common Effect model that is most appropriate to be used in estimating panel data. If Chi Square <0.05, the Fixed Effect Model is used. But if Chi Square> 0.05, the Common Effect Model is used; (2) Hausman Test is a statistical test to choose whether the Fixed Effect or Random Effect model is the most appropriate. If Chi Square $<0.05$, the Fixed Effect Model is used. But if Chi Square> 0.05, the random effect model is used; (3) Lagrange Multiplier test is performed if there is a difference in the model results between the chow test and the hausman test. If Prob. Breusch-Pagan $<0.05$ then what is used is the Random Effect Model. But if Prob. Breusch-Pagan>0.05 then what is used is the Common Effect Model.

\section{Hypothesis test}

\section{Coefficient of Determination (R2)}

The coefficient of determination is between zero and one (Ghozali, 2013). The higher $\mathrm{R} 2$, the better the regression model because it means that the independent variable is more able to explain the dependent variable.

\section{T Test (Partial Test)}

The T test is used to test the significance of the relationship between the variable $\mathrm{X}$ and the $\mathrm{Y}$ variable partially or it can be said that the test basically shows how far an independent variable is individually in explaining dependent variations (Ghozali, 2013). Partial significance test can be done through Wald test. Test criteria, namely: (1) The level of confidence used is $95 \%$ or a significance level of $5 \% \alpha=0.05$ ); (2) Criteria for acceptance or rejection of hypotheses based on significance $<0.05 \mathrm{H} 0$ are accepted.

\section{FINDING AND DISCUSSION \\ Research result \\ Descriptive statistics}


Table 1: Descriptive Statistics

\begin{tabular}{|c|c|c|c|}
\hline & EARNINGS M & FINANCIAL_DISTRES & TAX_MOTIVATION \\
\hline Mean & -0.114429 & -3.107341 & 0.015400 \\
\hline Median & -0.104910 & -0.201028 & 0.009599 \\
\hline Maximum & 0.366456 & 19.63869 & 0.060673 \\
\hline Minimum & -0.560258 & -48.01053 & 0.000000 \\
\hline Std. Dev. & 0.157387 & 12.54296 & 0.018090 \\
\hline Skewness & -0.054949 & -2.403894 & 1.121095 \\
\hline Kurtosis & 5.059063 & 9.207357 & 3.065209 \\
\hline Jarque-Bera & 7.972160 & 115.5865 & 9.434385 \\
\hline Probability & 0.018572 & 0.000000 & 0.008940 \\
\hline Sum & -5.149307 & -139.8303 & 0.692987 \\
\hline Sum Sq. Dev. & 1.089909 & 6922.338 & 0.014399 \\
\hline Observations & 45 & 45 & 45 \\
\hline
\end{tabular}

In Table 1 above shows that the magnitude of the earnings management variable has a maximum value of 0.366456 and a minimum of -0.560258 and has a mean value of -0.114429 , this means an average earnings management value of -0.114429 and a median value of -0.104910 while a standard deviation value of 0.157387 means this means deviation of earnings management value to its average value of 0.157387 . The magnitude of financial distress has a maximum value of 19.63869 and a minimum of 48.01053 and has a mean value of -3.107341 this means an average value of financial distress of -3.107341 and a median value of -0.201028 while the standard deviation value is of 12,54296 this means that there is a deviation in the value of financial distress to an average value of 12,54296 . The company with the highest financial distress was PT Berlian Laju Tanker Tbk in 2015, while the company with the lowest financial distress was also at PT Berlian Laju Tanker Tbk in 2018. The amount of tax motivation has a maximum value of 0.060673 and a minimum of 0.000000 and has a mean value of 0.015400 this case means the average value of tax motivation is 0.015400 and the median value is 0.009599 while the standard deviation value is 0.018090 , this means that there is a deviation in the value of tax motivation against the average value of 0.018090. The company with the highest tax motivation is PT WEHA Transportation Indonesia Tbk in 2018, while the company with the lowest tax motivation with a value of 0.000000 is PT Berlian Laju Tanker Tbk in 2016 to 2018, PT Cardig Aero Services Tbk in 2014 to 2015, and PT Trada Alam Minera Tbk in 2014. This shows that the company did not have any business effort to do tax motivation.

\section{Results of the Panel Data Regression Model Selection}

\section{Table 2: Chow Test Results}

\begin{tabular}{lrrr|}
$\begin{array}{l}\text { Redundant Fixed Effects Tests } \\
\text { Equation: Untitled } \\
\text { Test cross-section fixed effects }\end{array}$ & & & \\
& & & \\
\hline Effects Test & Statistic & d.f. & Prob. \\
\hline Cross-section F & 4.269268 & $(8,34)$ & 0.0012 \\
Cross-section Chi-square & 31.293516 & 8 & 0.0001 \\
\hline
\end{tabular}

Table 3: Hausman Test Results

Correlated Random Effects - Hausman Test

Equation: Untitled

Test cross-section random effects

Cross-section random

Chi-Sq. Statistic Chi-Sq. d.f. Prob.

The results of the chow test show that the cross-section probability value $\mathrm{F}$ (0.0012) is smaller than 0.05 , so it can be concluded that the fixed effect model is better used for estimating panel data compared to the common effect model. Then from the thirsty test that the value of the random cross-section probability $(0.0333)$ is smaller than 0.05 , so it can be concluded that the method chosen is better than the fixed effect method compared to the random effect.

Based on the results of the Chow test and the Hausman test it was proven that the Fixed Effect was more appropriate to be used in this study, compared to the Random Effect or Common Effect. From the results of the selection test panel data regression models 
present the same results in each test, these results can be seen in the table below, namely:

Table 4: Results of the Panel Data Regression Model Selection

\begin{tabular}{|l|l|l|}
\hline \multicolumn{1}{|c|}{ Metode } & \multicolumn{1}{c|}{ Pengujian } & \multicolumn{1}{c|}{ Hasil } \\
\hline Chow Test & Common Effect vs Fixed Effect & Fixed Effect \\
\hline Hausman Test & Fixed Effect vs Random Effect & Fixed Effect \\
\hline
\end{tabular}

Classic assumption test Multicollinearity Test

Table 5: Multicollinearity Test Results

\begin{tabular}{|l|c|c|}
\hline & FINANCIAL_D & TAX_MOTIVATION \\
\hline FINANCIAL_DISTRES & 1.000000 & 0.185766 \\
\hline TAX_MOTIVATION & 0.185766 & 1.000000 \\
\hline
\end{tabular}

To determine the presence or absence of multicollinearity is done by observing the correlation between independent variables. If the correlation number is greater than 0.8 , then there is indication of multicollinearity. From the table above it can be seen that the coefficient value of financial distress and tax motivation is 0.185766 , there is no variable that has a value above 0.8 , which means there is no correlation between strong variables. So it can be concluded that the research data are not multicollinearity.

\section{Heteroscedasticity Test}

Heteroscedasticity test aims to test whether or not the variance between residuals from one observation to another observation occurs in a regression model. The following are the results of the heteroscedasticity test in this study:

Table 6: Heteroscedasticity Test Results

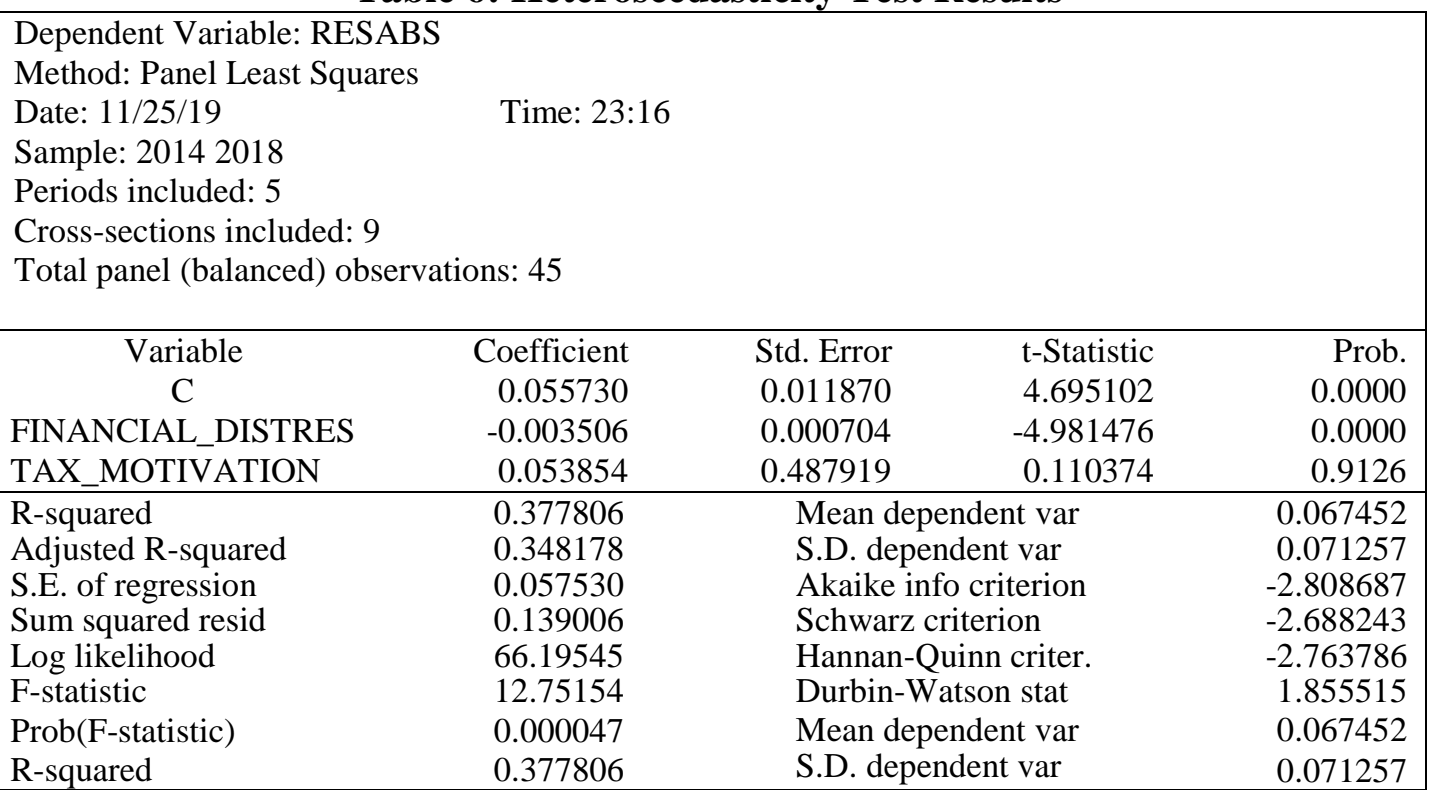

Heteroscedasticity test results show the probability value of financial distress free variables is 0.0000 smaller than the significance level of 0.05 so it can be concluded heteroscedasticity occurs. While the probability value of the tax motivation independent variable is 0.9126 which is greater than the significant level of 0.05 so it is concluded that heteroscedasticity does not occur.

\section{Autocorrelation Test}

Autocorrelation test aims to determine whether or not there is a correlation between one confounding factor with another in a regression model. The basis for making autocorrelation test decisions with the Durbin Watson Test, the following is the result of the autocorrelation test in this study:

Table 7: Autocorrelation Test Results

\begin{tabular}{|llll|}
\hline R-squared & 0.607166 & Mean dependent var & -0.114429 \\
Adjusted R-squared & 0.491627 & S.D.dependent var & 0.157387 \\
S.E.of regression & 0.112217 & Akaike info criterion & -1.328171 \\
Sum squred resid & 0.428153 & Schwarz criterion & -0.886543 \\
\hline
\end{tabular}




\begin{tabular}{|llll|}
\hline Log Likelihood & 40.88386 & Hannan-Quinn criter & -1.163537 \\
F-statistic & 5.255065 & Durbin-Watson stat & 2.054476 \\
Prob(F-statistic) & 0.000119 & & \\
\hline
\end{tabular}

The table above can be seen that the Durbin-Watson (dw) value in this research model is 2.054476, meaning that if the Durbin-Watson statistics range between values -2 to 2 or $-2<\mathrm{dw}<2$, then it shows that the regression model is not there is autocorrelation.

\section{Hypothesis test}

\section{Regression Model Fixed Effect Model and Regression Equation}

Table 8: Regression results for the Fixed Effect Method

\begin{tabular}{|c|c|c|c|c|}
\hline $\begin{array}{l}\text { Dependent Variable: EAR } \\
\text { Method: Panel Least Squa } \\
\text { Date: } 11 / 25 / 19 \\
\text { Sample: } 20142018 \\
\text { Periods included: } 5 \\
\text { Cross-sections included: } \\
\text { Total panel (balanced) ob }\end{array}$ & $\begin{array}{l}\text { INGS_MANAG } \\
\mathrm{s}\end{array}$ & EMENT & & \\
\hline Variable & Coefficient & $\begin{array}{l}\text { Std. } \\
\text { Error }\end{array}$ & $\begin{array}{l}\mathrm{t}- \\
\text { Statistic }\end{array}$ & Prob. \\
\hline $\mathrm{C}$ & -0.115968 & 0.029882 & $\begin{array}{l}- \\
3.880867\end{array}$ & 0.0005 \\
\hline $\begin{array}{l}\text { FINANCIAL_DISTRES } \\
\text { TAX_MOTIVATION }\end{array}$ & $\begin{array}{l}0.008132 \\
1.740845\end{array}$ & $\begin{array}{l}0.001806 \\
1.479584\end{array}$ & $\begin{array}{l}4.503714 \\
1.176577\end{array}$ & $\begin{array}{l}0.0001 \\
0.0001\end{array}$ \\
\hline \multicolumn{5}{|c|}{ Effects Specification } \\
\hline \multicolumn{5}{|c|}{ Cross-section fixed (dummy variables) } \\
\hline R-squared & 0.607166 & Mean dependent var & & -0.114429 \\
\hline Adjusted R-squared & 0.491627 & S.D.dependent var & & 0.157387 \\
\hline S.E.of regression & 0.112217 & Akaike info criterion & & -1.328171 \\
\hline Sum squared resid & 0.428153 & Schwarz criterion & & -0.886543 \\
\hline Log likelihood & 40.88386 & Hannan-Quinn criter & & -1.163537 \\
\hline F-statistic & 5.255065 & Durbin-Watson stat & & 2.054476 \\
\hline Prob(F-statistic) & 0.000119 & & & \\
\hline
\end{tabular}

The results of the output eviews above use the fixed effect estimation model. From the table above we get the panel data regression equation as follows: $\mathrm{Y}=-0.115968+0.008132 \mathrm{X} 1+1.740845 \mathrm{X} 2$

\section{Determination Coefficient Test $\left(\mathbf{R}^{2}\right)$}

In this study the determination coefficient R2 used is to use the adjusted Rsquared value when assessing the best regression model. Caused in this study to use more than one independent variable. Following are the results of the determination coefficient test using Eviews 8.0 software:

The table above shows that the adjusted R-squared value obtained is 0.491627 , showing that the variation in the independent variable is $49.16 \%$. While the difference of $50.84 \%$ is explained by other variables outside the chosen variable.

\section{DISCUSSION}

\section{Effect of Financial Distress on Earnings Management}

From the results of the partial hypothesis test ( $t$ test), it appears that the Financial Distress variable has a t-statistic value of 4.503714 with a significant value (prob.) 0.0001 smaller than 0.05. Thus, it can be concluded that the Financial Distress variable has a significant effect on Earnings Management positively, so that H1 is accepted. This shows that the greater the financial distress, the higher the possibility of the company to do earnings management.

The results of this study are supported by research conducted (Gupta \& Suartana, 2018) on banking sector companies listed on the Indonesia Stock Exchange in 2013-2016. The data analysis technique used is multiple linear regression. Financial Distress uses the altman $\mathrm{z}$-score. Based on the results of the analysis found that financial distress has a positive and significant effect on earnings management. The higher the level of financial distress of a company, the higher the earnings management of banking companies on the IDX.

\section{Effect of Tax Motivation on Earnings Management}


From the results of the partial hypothesis test ( $\mathrm{t}$ test), it appears that the variable motivation has a t-statistic value of 1.176577 with a significant value (prob.) 0.2475 greater than 0.05. Thus, it can be concluded that the Tax Motivation variable does not affect Earnings Management, so H2 is rejected. That is because the transportation sector service company based on the research sample of the average ratio ratio of Deferred Tax Expense to Total Assets of the previous year was not significant at $1.5 \%$. However, if in companies other than transportation sector there is a comparison of the ratio of Deferred Tax Expense to Total Assets of the previous year which is a significant percentage value, then the possibility of a tax motivation attempt is made.

Phillips et al. (2004) believe that earnings management activities by raising profits according to accounting are earnings management that maximizes profits without having to increase costs associated with the corporate tax. The research of Phillips et al. (2004) use changes in net deferred tax liabilities as a proxy for differences in earnings according to accounting with taxation in (Irreza \& Yulianti, 2012). The difference between accounting and fiscal financial statements is caused in the preparation of financial statements, accounting standards provide more flexibility for management in determining accounting principles and assumptions than is allowed according to tax regulations (Yulianti, 2005).

This is not in line with Scott (2000) in (Anasta, 2015) argues that there are several motivations that encourage managers to do earnings management, one of which is tax motivation. Management is motivated to practice earnings management to influence the amount of tax that must be paid by the company by lowering profits to reduce the tax burden that must be paid.

The results of this study are supported by (Dewi \& Ulupui, 2014) showing income tax has a negative effect on earnings management, where tax is not the main reason for companies to conduct earnings management.

\section{CONCLUSION AND SUGGESTION}

Based on the results of testing that has been done, it can be concluded that the Financial Distress Variable has a significant effect and has a positive relationship on Earnings Management. This shows that when a company experiences financial distress (financial distress), managers tend to do earnings management in order to keep providing positive information by displaying the performance of short-term earnings that always increases despite the fact that the company's condition is in trouble. Variable Tax Motivation has no effect on earnings management. This means that management is not motivated to do earnings management by reducing the tax burden to be paid and the tax factor is not a reason for management to manage earnings. Investors need to pay attention to factors that influence earnings management in order to determine the right investment choices and as expected; Companies can anticipate earnings management practices by management and take the right decisions if the company is in a financial distress position.

\section{REFERENCES}

Achyani, F., \& Lestari, S. (2019). Pengaruh Perencanaan Pajak Terhadap Manajemen Laba(Studi Empiris Pada Perusahaan Manufaktur Yang Terdaftar Di Bursa Efek Indonesia Tahun 2015-2017). JURNAL Riset Akuntansi dan Keuangan Indonesia, 4(1), 77-88.

Almashaqbeh, A. A., Abdul-Jabbar, H., \& Shaari, H. (2018). Real Earnings Management and Tax Considerations: A Conceptual Analysis. International Journal of Business Management and Commerce, 3(2), 25-35.

Almilia, L. S., \& Kristijadi. (2003). Analisis Rasio Keuangan untuk Memprediksi Kondisi Financial Distress Perusahaan Manufaktur yang Terdaftar di Bursa Efek Jakarta. JAAI, 7(2), 183-210.

Amanda, F., \& Febrianti, M. (2015). Analisis Pengaruh Beban Pajak Kini, Beban Pajak Tangguhan, dan Basis Akrual Terhadap Manajemen Laba. Ultima Accounting, 7(1), 70-86. 
Amidu, M., \& Yorke, S. M. (2017). Tax avoidance and earnings management of firms in Ghana: does the funding strategy matter? Int. J. Critical Accounting, 9(3), 238-264.

Anasta, L. (2015). Analisa Pengaruh Deferred Tax Asset, Deferred Tax Liabilities dan Tingkay Hutang Terhadap Manajemen Laba pada Perusahaan Sub Sektor Industri Makanan dan Minuman di Indonesia. Jurnal TEKUN, 4(2), 250-270.

Brigham, E., \& Houston, J. (2011). Manajemen Keuangan (Edisi Bahasa Indonesia ed.). Jakarta: Erlangga.

Dechow, P., \& Sweeney, A. (1995). Detecting EarningsManagement. The Accounting Review, 70(2).

Degeorge, F., Jayendu Patel, \& Richard Zeckhauser. (1999). Earnings Management to Exceed Thresholds. Journal of Business, 72(1), 1-33.

Dewi, L. S., \& Ulupui, I. K. (2014). Pengaruh Pajak Penghasilan dan Asset Perusahaan pada Earnings Management. E-Jurnal Akuntansi Universitas Udayana, ISSN: 2302-8556, 8(1), 250-259.

Ghozali, I. (2013). Aplikasi Analisis Multivariate dengan Program IBM SPSS 21 Update PLS Regresi. Semarang: Badan penerbit Universitas Diponegoro.

Gupta, A. T., \& Suartana, I. (2018). Pengaruh Financial Distress dan Kualitas Corporate Governance pada Manajemen Laba. E-Jurnal Akuntansi Universitas Udayana, ISSN: 2302-8556, 23(2), 1495-1520.

Harnanto. (2011). Akuntansi Perpajakan. Yogyakarta: BPFE-Yogyakarta.

Hartono. (2005). Hubungan Teori Signalling dengan Underpricing Saham Perdana di Bursa Efek Jakarta. Jurnal Bisnis dan Manajemen, 5(1), 35-50.

Hasibuan, R., \& Sucipto, T. N. (2019). Analisis Kebijakan Perencanaan Pajak (Tax Planning) Terhadap Penyesuaian Pendapatan dan Beban Dalam Perhitungan Pajak Penghasilan Pada PT. Kawasan Industri Medan. Jurnal Mutiara Akuntansi, 3(1), 33-42.

Hastuti, S. (2011). Titik Kritis Manajemen Laba pada Perubahan Tahap Life Cycle Perusahaan: Analisis Manajemen Laba RIIL dan Manajemen Laba Akrual. Jurnal Akuntansi dan Keuangan Indonesia, 8(2), 107-122.

Hayn, C. (1995). The Information Content of Losses. Journal of Accounting and Economics, 20(2), 125-153.

Irreza, \& Yulianti. (2012). Penggunaan Komponen Pembentuk Pajak Tangguhan dalam Mendeteksi Manajemen Laba. Jurnal Akuntansi dan Keuangan Indonesia, 9(1), 68-82.

Jensen, \& Meckling. (1976). The Theory of The Firm: Manajerial Behaviour, Agency Cost, and Ownership Structure. Journal of Financial and Economics, 3, 305360.

Khalida, H., \& Tarmizi, M. (2015). Deffered Tax Expense, Profitability, Discretionary Accruals Dan Manajemen Laba. Journal Applied Buisiness and Economics, 1(4).

Kodriyah, \& Fitri, A. (2017). Pengaruh Free Cash Flow dan Leverage Terhadap Manajemen Laba Pada Perusahaan Manufaktur di BEI. Jurnal Akuntansi pISSN 2339-2436 e-ISSN 2549-5968, 3(2), 64-76.

Kusumawardani, N. F., \& Dewi, R. (2016). Motivasi Bonus, Pajak, dan Utang dalam Tindakan Manajemen Laba (Studi Perusahaan Manufaktur Yang Terdaftar Di 
Bursa Efek Indonesia). Media Riset Akuntansi, Auditing \& Informasi, 16(1), 79-90.

M. Humeedat, M. (2018). Earnings Management to Avoid Financial Distress and Improve Profitability: Evidence from Jordan. International Business Research ISSN 1913-9004 E-ISSN 1913-9012 Published by Canadian Center of Science and Education, 11(2), 222-230.

M., B., \& Luca R., D. (2015). Financial Distress and Earnings Manipulation: Evidence from Italian SMEs. Journal of Accounting and Finance ISSN: 22493964 \& E-ISSN: 2249-3972, 4(1), 42-51.

Magister Akuntansi. (2015, 8 -). Magister Akuntansi. Retrieved 10 8, 2019, from Magister Akuntansi: https://magisterakutansi.blogspot.com/2015/08/grandtheory.html

Marliana, R. (2017). Manajemen Laba di Indonesia dan Malaysia dalam Era Masyarakat Ekonomi ASEAN. Jurnal Akuntansi, 12(1), 20-36.

Munawir. (2010). Analisis Laporan Keuangan (Edisi Keempat ed.). Yogyakarta: Yogyakarta, Liberty.

Myers, L., \& Skinner, D. (2000). Earnings Momentum and Earnings Management. Working Paper, University of Michigan.

Nur Perwita, A., \& Anita Nuswantara, D. (2019). Earnings Management Within Three Tax Reforms Era. International Conferenceon Economics, Education, Business and Accounting, KnE Social Sciences, 2019, 915-926.

Pramitasari, F., \& Christiawan, Y. J. (2017). Pengaruh Beban Pajak Penghasilan Terhadap Manajemen Laba pada Perusahaan Sektor Perdagangan, Jasa dan Investasi Periode 2010-2015 yang Terdaftar di Bursa Efek Indonesia dengan Firm Size dan Leverage sebagai Variabel Kontrol. Business Accounting Review, 5(2), 481-492.

Rinaldi, M. (2015, 4 18). Signalling Theory \& Agency Theory. Retrieved 10 8, 2019, from Signalling Theory \& Agency Theory: http://muhammadrinaldi01.blogspot.com/2015/04/signalling-theory-agenytheory.html

Roychowdhury, S. (2006). Earnings Management Through Real Activities Manipulation. Journal of Accounting and Economics, 42(3), 335-370.

Schipper, K. (1989). Commentary on Earnings Management. Accounting Horizons, 3(4), 91-102.

Scott, R. (2000). Financial Accounting Theory.

Setiani, N. M., Andini, R., \& Oemar, A. (2018). Pengaruh motivasi wajib pajak dan pengetahuan perpajakan terhadap kepatuhan wajib orang pribadi dengan kesadaran wajib pajak sebagai variabel intervening. Journal of Accounting.

Sugiyono. (2012). Metode Penelitian Kuantitatif Kualitatif \& RND.

Sugiyono. (2014). Metode Penelitian Kuantitatif, Kualitatif, dan kombinasi (Mixed Methods).

Suranggane, Z. (2007). Analisis Aktiva Pajak Tangguhan dan Akrual Sebagai Prediktor Manajemen Laba: Kajian Empiris pada Perusahaan Manufaktur yang Terdaftar di BEJ. Jurnal Akuntansi dan Keuangan Indonesia @Fakultas Ekonomi Universitas Diponegoro, 4(1), 77-94. 
Sutrisno, M., Sari, I. A., \& Astuti , Y. P. (2018). Pengaruh Perencanaan Pajak Dan Insentif Non Pajak Terhadap Manajemen Laba Pada Perusahaan Manufaktur Yang Terdaftar Di Bursa Efek Indonesia Tahun 2013-2017. X(I).

Theodorus, M. G., \& Hapsari, Y. D. (2017). Analisis Faktor - Faktor yang mempengaruhi keberhasilan Turnaround pada Perusahaan yang Mengalami Financial Distress di Industri Makanan dan Minuman Yang Terdaftar di BEI Periode 2011 - 2015. 9, 16-36.

Theodorus, M. G., \& Hapsari, Y. D. (n.d.). Analisis Faktor - Faktor yang mempengaruhi keberhasilan Turnaround pada Perusahaan yang Mengalami Financial Distress di Industri Makanan dan Minuman Yang Terdaftar di BEI Periode 2011 - 2015. 16-36.

Tresnaningsih, E. (2008). Manajemen Laba pada Perusahaan dengan Permasalahan Free Cash Flow dan Peran Moderasi dari Monitoring Eksternal. Jumal Akuntansi dan Keuangan Indonesia, 5(1), 30-49.

Undang-Undang Republik Indonesia Nomor 16 Tahun 2009. (n.d.).

Wijaya, V. A., \& Christiawan, Y. J. (2014). Pengaruh Kompensasi Bonus, Leverage, dan Pajak Terhadap Earning Management Pada Perusahaan Yang Terdaftar Di Bursa Efek Indonesia Tahun 2009-2013. TAX \& ACCOUNTING REVIEW, 4(1).

Wulandari, S., \& Kusuma, I. W. (2013). Manajemen Laba dengan Classification Shifting: Pengujian Laba Usaha dan Pos Luar Biasa (Studi Empiris di NegaraNegara ASEAN). Jurnal Akuntansi dan Keuangan Indonesia, 10(1), 1-19.

Yuliana, C. (2011). Pengaruh Leverage, Pergantian CEO dan Motivasi Pajak terhadap Manajemen Laba. JRAK, 7(1), 19-29.

Yulianti. (2005). Kemampuan Beban Pajak Tangguhan dalam Mendeteksi Manajemen Laba. Jurnal Akuntansi dan Keuangan Indonesia @Departemen Akuntansi FEUI, 2(1), 107-129.

Zang, A. (2006). Evidence on the Tradeoff between Real Manipulation and Accrual Manipulation. Working Paper, Duke University. 